\title{
Propagandowa działalność komitetów powiatowych PZPR na Lubelszczyźnie w świetle działalności bibliotek partyjnych 1948-1952
}

ABSTRAKT: Niniejszy artykuł ma na celu ukazanie propagandowej działalności Polskiej Zjednoczonej Partii Robotniczej w pierwszych latach jej funkcjonowania (1948-1952) przez pryzmat organizacji bibliotek komitetów powiatowych. Biblioteki stanowily bardzo istotny element wewnątrzpartyjnego systemu oświatowego, będąc wsparciem dla tak istotnego z perspektywy partii samokształcenia. Zarówno ich zasób, jak i fachowy personel miały zachęcać do częstego korzystania z biblioteki, a tym samym pozytywnie wpływać na intelektualny rozwój członków partii. Bazując na sprawozdaniach bibliotecznych autorka przedstawiła stopień przygotowania partii do prowadzenia działań oświatowych i propagandowych $\mathrm{w}$ terenie, a także poziom jej zorganizowania.

SŁowa KLuczowe: biblioteka komitetu powiatowego Polskiej Zjednoczonej Partii Robotniczej, oświata partyjna PZPR, propaganda partyjna PZPR.

Oświata i kultura w systemach totalitarnych odgrywają istotną rolę jako doskonałe narzędzie indoktrynacji i kształtowania kolejnych pokoleń posłusznych obywateli. Oba te przejawy ludzkiej działalności łączy w sobie biblioteka. W Polsce doby stalinizmu istniało wiele bibliotek partyjnych różnych szczebli, wśród których znalazły się również te tworzone przy komitetach powiatowych Polskiej Zjednoczonej Partii Robotniczej (dalej: PZPR). Miały one jedno podstawowe zadanie - stanowiły zaplecze naukowe do prowadzenia kursów doszkalających oraz tworzenia przy nich grup samokształceniowych. Co ciekawe, analizując propagandową działalność PZPR badacze bardzo rzadko poświęcają uwagę bi- 
bliotekom partyjnym, jakby nie do końca zdając sobie sprawę z ich roli w tym obszarze. O bibliotekarzach partyjnych $\mathrm{w}$ województwie warszawskim pisała Agnieszka Chamera-Nowak ${ }^{1}$, a o propagandowej działalności bibliotek w dobie stalinizmu Dariusz Jarosz ${ }^{2}$, jednak te dwie publikacje w znikomym stopniu wyczerpują temat bibliotek partyjnych. Tymczasem można wysnuć hipotezę, że to właśnie one znalazły się na przedpolu walki o stworzenie silnej i jednomyślnej partii. Tak przynajmniej może wynikać z treści dokumentu z 1950 r., w którym kierownik Biblioteki Komitetu Centralnego PZPR, W. Michalska, informuje, że zgodnie z uchwałą z 1 III tego roku wszystkie biblioteki partyjne stanowią element ośrodków szkolenia partyjnego. Tym samym Referat Sieci Bibliotecznej został przeniesiony do Centralnego Ośrodka Szkolenia Partyjnego w Warszawie i to do niego biblioteki niższego szczebla miały wysyłać sprawozdania ${ }^{3}$. Niemalże od samego początku partia dostrzegała rolę uważnej i samodzielnej lektury w procesie kształcenia nowych jej członków, tworząc przy ośrodkach szkolenia partyjnego czytelnie, których dobrze przeszkolony personel miał (przynajmniej w założeniu) nakierowywać uczestników szkoleń na odpowiednie treści i tym samym stanowić podstawę prężnie działającego ośrodka ${ }^{4}$.

Przygotowywane na polecenie partii książki, skrypty oraz broszury miały pomóc $\mathrm{w}$ zrozumieniu tematyki szkoleń, uzupełniać profil samokształcenia, a także służyć masowej indoktrynacji. $\mathrm{Z}$ uwagi na fakt, że w szkoleniach brali udział przede wszystkim przedstawiciele klasy robotniczej, literatura, z jaką spotkali się na kursach, była nierzadko pierwszą, jaką kiedykolwiek przeczytali. Dzięki temu partia mogła bardzo swobodnie manipulować serwowanymi uczestnikom szkoleń treściami. Nie sięgano po podręczniki z dwudziestolecia międzywojennego, zastępując je książkami powstającymi najczęściej

1 A. Chamera-Nowak, Biblioteki i bibliotekarze partyjni $w$ województwie warszawskim w latach 1949-1954 w świetle dokumentów Komitetu Centralnego PPR oraz Warszawskiego Komitetu Wojewódzkiego PZPR, „Z badań nad książką i księgozbiorami historycznymi”, t. 10, 2016, s. $279-294$.

2 D. Jarosz, Codzienna mobilizacja. O propagandzie czytelnictwa ksiązek w Polsce stalinowskiej i trudnościach jej badania, „Z badań nad książką i księgozbiorami historycznymi”, t. 5, 2011, s. 295-306.

3 Archiwum Państwowe w Lublinie, Komitet Powiatowy Polskiej Zjednoczonej Partii Robotniczej (dalej: KP PZPR) w Lubartowie, sygn. 598, Referat Sieci Bibliotecznej przy KC PZPR do KP PZPR w Lubartowie, k. 56.

4 K. Zawadka, Komitet Wojewódzki PZPR w Lublinie 1948-1956. Struktura - ludzie - mechanizmy funkcjonowania, Lublin 2014, s. 83. 
w Związku Radzieckim lub pod kierownictwem Wydziału Propagandy. Obowiązkowe były też publikacje Marksa, Engelsa, Lenina i Stalina ${ }^{5}$.

Skrypty wielu wykładów przygotowali uznani propagandziści partii, jak Edward Ochab, Włodzimierz Sokorski i Stefan Żółkiewski. Podczas kursów odczytywano też wiele artykułów z prasy partyjnej. Takie tytuły, jak „Głos Ludu”, „Kuźnica”, „Notatnik Referenta”, czy „Trybuna Ludu” stosunkowo regularnie publikowały teksty, których treść stanowiła gotowy materiał do lekcji. Ponadto powstawały też specjalne serie wydawnictw, jak Biblioteczki Szkolenia Partyjnego i Materiały do szkolenia aktywu partyjnego, będące zbiorem materiałów do kolejnych kursów ${ }^{6}$.

Z tak ogromną rozwagą i starannością przygotowane treści stanowiły podstawę szkoleń partyjnych, których charakter doskonale odzwierciedla instrukcja z 6 VII 1949 r., adresowana do kierownika Wydziału Propagandy KW PZPR w Lublinie z Wydziału Szkolenia Partyjnego KC. Dokument zawiera ogólne wytyczne dotyczące kursów zaplanowanych na jesień tego roku. Podstawowy podział zakładał szkolenia, które nie wymagały oderwania od pracy i takie, przy okazji których konieczne były wyjazdy do ośrodków szkoleniowych. Te pierwsze podzielono na podstawowe kursy miejskie i wiejskie, wieczorowe szkoły polityczne i samokształcenie. W przypadku szkoleń w ośrodkach miejskich obowiązywała zasada, że przy każdym zakładzie pracy powinno się zorganizować chociaż jeden kurs?.

Wiejskie szkolenia organizowano przy komitetach gminnych, w większych gromadach lub PGR-ach. Kursy miały tyle samo lekcji co miejskie, ale z uwagi na mniejszą częstotliwość spotkań trwały o wiele dłużej. Z kolei wieczorowe szkoły polityczne adresowane były do aktywu partyjnego oraz do osób, które szczególnie wykazały się na szkoleniach masowych. Zajęć było tutaj więcej, bo od 30 do 35 spotkań raz w tygodniu, co dawało niespełna osiem miesięcy kursu. Organizowano je przy komitetach powiatowych, miejskich oraz w dużych zakładach pracy. Szkolenie nadzorował jeden główny wykładowca, ale kursanci mieli też zajęcia ze specjalistami, którzy odpowiadali za wąskie dziedziny nauki. Najwyższą jednak formą szkoleń, bez oderwania od pracy, było samokształcenie,

5 B. Cichocki, K. Jóźwiak, Najważniejsze sa kadry. Centralna Szkoła Partyjna PPR/PZPR, Warszawa 2006, s. 136-137.

6 Ibidem, s. 137.

7 APL, KP PZPR w Lublinie, sygn. 2317, Instrukcja do Kierownika Wydziału Propagandy KW PZPR w Lublinie, k. 11. 
wymagające rzecz jasna sprawnie działającej biblioteki partyjnej z odpowiednio wyposażonym księgozbiorem ${ }^{8}$.

Na potrzeby szkoleń z oderwaniem od pracy stworzono szkoły wojewódzkie i powiatowe, a wkrótce miała też powstać szeroka sieć ośrodków szkolenia partyjnego. Kursy w ośrodkach powiatowych trwały od czterech do sześciu tygodni, a w wojewódzkich pół roku, z tym że w wyjątkowych przypadkach materiał sześciomiesięczny można było omówić w trzy miesiące. Do szkół takich trafiali tylko przedstawiciele aktywu partyjnego ${ }^{9}$.

Kursy miejskie i wiejskie składały się z pięciu tematów, które miały ogólnie wprowadzić ich uczestników w kwestie ideologiczne. W przypadku wsi dokładano jeszcze zagadnienia z rolnictwa. Wieczorowa szkoła polityczna składała się natomiast z czterech cykli: Podstawowe wiadomości o ekonomii, ZSRR - kraj socjalizmu, Nasza partia i Budujemy podstawy socjalizmu. W szkole powiatowej nieznacznie rozszerzano tę tematykę, natomiast w szkole wojewódzkiej wprowadzano dodatkowo m.in. cykl o historii międzynarodowego ruchu robotniczego ${ }^{10}$.

Oczywiście, wytyczne często się zmieniały, ale już na początku funkcjonowania PZPR sieć szkoleń była dobrze rozbudowana, a ich treść przygotowywano z myślą o różnych adresatach. O ile jednak broszury i zeszyty z materiałami bez problemu, przy niskim nakładzie finansowym, można było rozprowadzać wśród kursantów, o tyle książki, z których korzystali przede wszystkim członkowie aktywu partyjnego, łatwiej było przechowywać i udostępniać właśnie dzięki bibliotekom. Tak często podkreślana $\mathrm{w}$ różnych dokumentach rola samokształcenia zdaje się sugerować, że biblioteki partyjne szybko staną się jednym z najistotniejszych elementów wewnątrzpartyjnej oświaty. Jednak zachowane materiały źródłowe przedstawiają nam obraz zgoła odmienny, zwłaszcza w pierwszych latach działalności partii. Szczególnie cenne informacje można wydobyć przyglądając się bibliotekom komitetów powiatowych, które stanowiły środkowy szczebel $\mathrm{w}$ hierarchii i przynajmniej w teorii winny być pilnie kontrolowane przez organy nadrzędne, a jednocześnie dawać przykład innym bibliotekom.

Podstawowym źródłem informacji o losach poszczególnych bibliotek komitetów powiatowych są sprawozdania biblioteczne. Dotarcie do nich nastręczać może jednak sporo trudności. W źródłach, które pozostały po komitetach powiatowych zaledwie w dwóch przypadkach (Lubartów i Radzyń Podlaski) tego

\footnotetext{
8 Ibidem, k. 12.

9 Ibidem, k. 12-13.

10 Ibidem, k. 14.
} 
typu materiały znalazły się w odrębnych teczkach, reszta trafiła do teczek zbiorczych ze sprawozdaniami lub z korespondencją wychodzącą z komitetów powiatowych. Kwerenda w tego rodzaju jednostkach nie jest najowocniejsza i wymaga sporo czasu, niemniej z odnalezionych dokumentów wyłania się bardzo ciekawy obraz bibliotek komitetów powiatowych, jak i samej działalności partii w obszarze edukacji i propagandy.

\section{Ogólne zasady działania bibliotek przy komitetach powiatowych PZPR}

Już w dokumencie z 22 IX 1949 r., wydanym przez Wydział Propagandy przy Komitecie Wojewódzkim PZPR w Lublinie, podkreślano ogromną rolę bibliotek partyjnych w ideologicznym kształtowaniu członków partii. Jednocześnie jednak zwrócono uwagę, że większość bibliotek zarządzanych jest w sposób niezgodny z zaleceniami. Wskazywano m.in. na brak wykwalifikowanego personelu, odpowiedzialnego za ich prowadzenie, nieczytelną ewidencję wypożyczenia oraz na brak zaangażowania w propagowanie czytelnictwa ${ }^{11}$.

W dalszej części tego dokumentu podano zalecenia, jakie powinny zostać zrealizowane, by usprawnić działalność bibliotek komitetów powiatowych. Po pierwsze trzeba było natychmiast wytypować ludzi odpowiedzialnych za prowadzenie bibliotek. Powinny to być osoby, które nie są obarczone innymi obowiązkami, ale mogli to też być towarzysze pełniący na co dzień inne funkcje. Ważne, by ktoś w ustalonych dniach tygodnia i godzinach przebywał w bibliotece. Co ciekawe, pracę w bibliotece traktowano jak partyjny obowiązek, więc była to właściwie funkcja bezpłatna i jedynie w niektórych przypadkach przewidywano symboliczne wynagrodzenie. Ponadto, komitety miały wygospodarować odpowiednie miejsce na księgozbiór i inne materiały przydatne do pracy w bibliotece. Jeśli brakowało samodzielnego pomieszczenia, mogła to być specjalnie wydzielona część w czyimś gabinecie. Ważne, żeby bibliotekarz mógł w spokoju i dogodnych warunkach pracować. Wszystkie zmiany miano wprowadzić do 1 X 1949 r., do tego czasu komitety miały też przesłać spis posiadanych książek. W dokumencie zapowiedziano także specjalną odprawę dla bibliotekarzy w KW PZPR w Lublinie, której termin jednak nie został podany ${ }^{12}$.

11 APL, KP PZPR w Chełmie, sygn. 656, Wydział Propagandy KW do I Sekretarzy i Instruktorów Propagandy KP PZPR w województwie lubelskim, k. 59.

12 Ibidem. 
Jak widać, zawód bibliotekarza z punktu widzenia partii był uznawany za istotny, ale mimo to traktowany po macoszemu. Tymczasem wiadomo, że już pod koniec $1948 \mathrm{r}$. opracowany został projekt szkolenia korespondencyjnego dla bibliotekarzy komitetów powiatowych, miejskich i gminnych, a także szkół partyjnych i świetlic. Szkolenie miało rozpocząć się 1 I 1949 r. i było obowiązkowe dla pracowników bibliotek przy komitetach. Do 31 XII tego roku wszystkie KP miały wysłać pełną listę kursantów. Za szkolenie płacił w połowie komitet, a w połowie uczestnik. Kurs składał się z dwóch części - przeszkolenia bibliotecznego i partyjno-politycznego. Pierwsze materiały miały zostać wysłane już w styczniu, a zgłoszenia można było przesyłać do 23 XII 1949 r. $^{13}$

Do kształcenia pracowników bibliotek służyły także konferencje. Przykładem może być jednodniowy zjazd, który odbył się 16 XII 1949 r. w siedzibie KW PZPR w Lublinie. Na spotkaniu tym obowiązkowo mieli się stawić bibliotekarze powiatowi. Spotkanie rozpoczęło się o godzinie 9.00 i składało z trzech bloków tematycznych: sprawozdania rocznego z działalności bibliotek, sprawozdania z techniki bibliotecznej oraz omówienia działalności komitetów bibliotecznych i kursu bibliotekarskiego ${ }^{14}$.

Ciekawą inicjatywą, mającą zachęcić pracowników bibliotek do wzmożonej pracy i osiągania lepszych wyników na polu propagandy, było współzawodnictwo biblioteczne. W dokumencie z listopada 1949 r. jest mowa o rozgrywkach między wojewódzkimi bibliotekami Lublina i Białegostoku. Ich wynik zależał też od stanu uporządkowania bibliotek przy KP. Zawody miały trwać sześć tygodni. Powiaty musiały do 28 XI wysłać sprawozdania, które przez ręce KW trafiały do Komitetu Centralnego i to właśnie tam miano wybrać zwycięzcę. Na czas współzawodnictwa wstrzymano dostawy książek, które miały być wznowione w styczniu lub lutym $1950 \mathrm{r}^{15}$

Księgozbiór biblioteki komitetów przejmowały po tych działających za czasów $\mathrm{PPR}^{16}$, a w późniejszym okresie otrzymywały lub kupowały książki za pośrednictwem Referatu Sieci Bibliotecznej przy KC PZPR (do 1 XI 1949 r.), lub bezpośrednio od wydawców ${ }^{17}$. Przykładowo, do biblioteki Komitetu Powiatowe-

${ }_{13}$ APL, KP PZPR w Kraśniku, sygn. 547, KW PZPR Wydział Propagandy, Oświaty i Kultury do KP PZPR województwa lubelskiego, k. 1.

${ }^{14}$ KP PZPR w Chełmie, sygn. 656, Wydział Biblioteczny do KP PZPR, k. 123.

15 Ibidem, k. 117.

16 APL, KP PZPR w Puławach, sygn. 445, Sprawozdanie opisowe wg formularza nr 1 i 2, k. 29.

17 KP PZPR w Lubartowie, sygn. 553, Spółdzielnia Wydawnicza „Książka i Wiedza” do KP PZPR w Lubartowie, k. 92. 
go w Chełmie przysłano w styczniu 1950 r. książki Synowie ziemi mazowieckiej oraz O wielkiej wojnie Józefa Stalina, do tego 63 karty katalogowe. Koszty miały być wliczone do budżetu Komitetu Powiatowego ${ }^{18}$.

Należy w tym miejscu zasygnalizować, że biblioteki otrzymywały również specjalne instrukcje, w których znajdowała się lista książek obowiązkowych i obligatoryjnych do zakupu w danym miesiącu. Przykładem tego jest dokument z 30 XII 1949 r. z Komitetu Powiatowego w Lubartowie. Co ciekawe, pismo nie zostało wystawione przez organ partyjny, a przez Spółdzielnię Wydawniczą „Książka i Wiedza”. W oparciu o rozporządzenie KC PZPR z 14 XI 1949 r. o bibliotekach, wydawnictwo przesłało listę książek na dwa miesiące. W dokumencie zaznaczono, że wszystkie tytuły zostały zatwierdzone przez KC PZPR i należy je zakupić $\mathrm{z}$ budżetu na miesiące listopad i grudzień. Kwota przewidywana na każdy miesiąc wynosiła 5000 złotych. W wykazach, które zostały omówione w dalszej części pracy, pojawiają się trzy rodzaje tytułów: „obowiązkowe”, oznaczone jednym krzyżykiem; "potrzebne”, zaznaczone dwoma i „uzupełniające”, obok których widniały trzy krzyżyki ${ }^{19}$.

Księgozbiory wszystkich bibliotek podlegały kontroli i na bieżąco usuwano książki, których treści uznano za szkodliwe. Były to akcje o charakterze poufnym. Z odnalezionych materiałów wynika, że jedna $\mathrm{z}$ nich została przeprowadzona już w 1949 r. Oczyszczanie bibliotek miały przeprowadzić specjalnie do tego celu powołane trzyosobowe zespoły, w skład których wchodził jeden członek KP, jeden przewodniczący miejskiej lub powiatowej rady narodowej oraz inspektor szkolny. Kontrola przebiegała na podstawie otrzymanego wykazu, który po zakończeniu akcji miał być zwrócony do KC. Szkodliwe książki przekazywano do inspektoratu szkolnego, a następnie do kuratorium. W trakcie pracy trójki mogły zgłaszać dodatkowe uwagi, dotyczące możliwie szkodliwych wydawnictw, a zgłoszenia te miały posłużyć do stworzenia kolejnej listy ${ }^{20}$.

Do dokumentu dołączono również ankietę sprawozdawczą z przeprowadzonej akcji. Podzielona była na dwie części i zawierać miała informacje o liczbie skontrolowanych bibliotek, ilości usuniętych książek, tytuły, autorów oraz lata wydania publikacji, które dodatkowo uznano za szkodliwe oraz ogólne uwagi dotyczące przebiegu oczyszczania bibliotek ${ }^{21}$.

${ }^{18}$ KP PZPR w Chełmie, sygn. 766, Wydział Propagandy, Oświaty i Kultury KW do KP PZPR w Chełmie, k. 9.

19 Ibidem.

${ }^{20}$ KP PZPR Puławy, sygn. 434, Instrukcja o czyszczeniu bibliotek, k. 7-8.

${ }^{21}$ Ibidem, k. 9. 
Kolejna instrukcja, dotycząca akcji oczyszczania księgozbiorów bibliotek KP, pochodzi z 8 VIII 1952 r. Podobnie jak wcześniej, była to akcja o charakterze poufnym, przeprowadzana przez trzyosobowy zespół. Trójki miały za zadanie samodzielnie zaplanować kolejność przeprowadzania kontroli, wycofać na podstawie księgi inwentarzowej książki zdezaktualizowane, dopilnować umieszczenia tych egzemplarzy na liście ubytków, sporządzić protokól, a wycofane egzemplarze przesłać do KW. Kontrola powinna była być przeprowadzona do 30 IX, a jej przebieg musiał obserwować bibliotekarz. W załączniku do dokumentu znalazł się spis takich książek wraz z uwagą, że należy bezwzględnie usunąć wszystkie książki Władysława Gomułki i Mariana Spychalskiego. Oprócz publikacji tych dwóch autorów z księgozbiorów należało wyłączyć następujące pozycje: Ze stanowiska socjalizmu polskiego Józefa Cyrankiewicza, Na progu wolności Stefana Matuszewskiego, Spółdzielczość w walce o wzrost produkcji rolnej Henryka Minca, Polityka PPR na wsi, My sami w nowej gospodarce Adama Rapackiego, Po rozmowie $z$ przyjacielem $z$ PPS, O masowa milionowa partię Romana Zambrowskiego, Od demokracji ludowej do socjalizmu i $W$ walce o dobrobyt na wsi $i^{22}$.

Należy pamiętać, że partia cały czas czuwała nad stanem bibliotek powiatowych. $\mathrm{Z}$ zachowanych materiałów wynika, że biblioteki powiatowe były kontrolowane zarówno ze szczebla wojewódzkiego, jak i centralnego. Podstawową formą kontroli były sprawozdania, które stanowią najważniejsze źródło informacji o działalności bibliotek powiatowych. Zgodnie z okólnikiem z 11 X 1949 r. biblioteki miały obowiązek złożyć sprawozdanie z działalności do 28. dnia każdego miesiąca, z możliwością przedłużenia tego terminu do 4. dnia następnego miesiąca. Sprawozdania miały trafić do Działu Biblioteki KW PZPR w Lublinie na ręce kierowniczki Katarzyny Gruchalskiej. Kładziono nacisk na to, by w tym szczególnym czasie, gdy dopiero formowano biblioteki, pilnować częstotliwości nadsyłania sprawozdań. Informacje w nich zawarte miały dotyczyć praktycznej strony działalności biblioteki, jej księgozbioru oraz rozwoju czytelnictwa. Dokument niesie za sobą jeszcze jedną, istotną informację - biblioteki komitetów powiatowych sprawowały pieczę nad punktami bibliotecznymi przy komitetach gminnych i podstawowych organizacjach partyjnych ${ }^{23}$.

${ }^{22}$ APL, KP PZPR w Tomaszowie Lubelskim, sygn. 604, Wydział Propagandy do I Sekretarza KP PZPR, k. 113-114.

${ }^{23}$ APL, KP PZPR w Zamościu, sygn. 335, Okólnik Wydziału Propagandy KW PZPR do KP PZPR województwa lubelskiego, k. 187. 
Jak wyglądały takie sprawozdania? Z Komitetu Centralnego otrzymywano najczęściej wzory formularzy. Nieco różniły się one między sobą. I tak formularz z października 1949 r. zawierał pytania o to, ile książek przybyło w ciągu miesiąca, jaki jest ostatni numer w księdze inwentarzowej, jaki katalog wprowadzono, czy zatrudniono bibliotekarza, czy uruchomiono czytelnię pism, bibliotekę i wypożyczalnię, ilu obsłużono czytelników, ile wypożyczono książek i ilu jest użytkowników w ogóle ${ }^{24}$. W trochę zmienionej formie było to w przypadku sprawozdań z Radzynia Podlaskiego, gdzie do wymienionych pytań dodano jeszcze zapytania o dni i godziny otwarcia, rok założenia biblioteki oraz czy jest w komitecie gabinet partyjny ${ }^{25}$.

Z kolei formularz z 1950 r. był o wiele bardziej szczegółowy. Pojawiają się w nim pytania nie tylko o bibliotekarza i jego wynagrodzenie, ale też o zatrudnionych przy bibliotece pracowników społecznych i etatowych. Ponadto pytano, czy zatrudniony bibliotekarz przeszedł szkolenie partyjne, kurs bibliotekarski oraz czy należy do Związku Bibliotekarzy i Archiwistów Polskich. Pytano też o powiatowe ośrodki szkoleniowe, materiały, jakie należało dostarczyć bibliotece, prenumerowane czasopisma, mogące pomóc bibliotekarzowi w jego pracy (np. „Poradnik Biblioteczny”) oraz o to, czy biblioteka jest zainteresowana zakupem broszur do nauki języka rosyjskiego ${ }^{26}$. Oprócz formularzy, które były o wiele bardziej czytelne, można było stosować formę opisową sprawozdań. Tak było chociażby w przypadku Radzynia Podlaskiego $0^{27}$.

Gdy biblioteki nie nadsyłały sprawozdań, otrzymywały pisma ponaglające, w których przypominano o ciążącym na komitecie powiatowym obowiązku dbania o regularne nadsyłanie informacji o działalności biblioteki. Takie ponaglenie z Komitetu Centralnego otrzymała biblioteka KP w Chełmie. $\mathrm{W}$ treści dokumentu zaznaczono, że z powodu braku sprawozdań zmniejsza się subwencję na książki. Jeśli komitet nie wysłałby kolejnych sprawozdań, to subwencja zostałaby całkowicie odebrana i wstrzymano by wysyłanie kolejnych książek ${ }^{28}$.

${ }^{24}$ KP PZPR w Lubartowie, sygn. 564, Sprawozdanie bibliotekarza przy KP PZPR w Lubartowie, k. 3.

${ }^{25}$ APL, KP PZPR w Radzyniu Podlaskim, sygn. 563, Sprawozdanie bibliotekarza przy KP PZPR w Radzyniu Podlaskim, k. 14.

${ }^{26}$ KP PZPR w Kraśniku, sygn. 616, Formularz nr 1 za marzec 1950, k. 52.

${ }^{27}$ KP PZPR w Radzyniu Podlaskim, sygn. 563, Sprawozdanie bibliotekarza przy KP PZPR w Radzyniu Podlaskim, k. 12.

${ }^{28}$ KP PZPR w Chełmie, sygn. 656, Wydział Propagandy KC do KP PZPR w Chełmie, k. 18. 
Inną formą kontroli, która pojawiła się już 1949 r., były komitety biblioteczne. Miały działać na szczeblu wojewódzkim, powiatowym i gminnym. W ich skład wchodzili członkowie partii. Komitety te miały na celu nadzorować pracę bibliotek i rozpropagowywać czytelnictwo. Nie wiadomo jednak, czy miały jakikolwiek wpływ na działanie bibliotek partyjnych ${ }^{29}$.

\section{Biblioteka KP PZPR w Lubartowie}

Sprawozdania biblioteki KP PZPR w Lubartowie, zachowane z okresu od sierpnia 1949 do grudnia 1950 r., napływały regularnie, co mogło wynikać z faktu, że niemal od początku była tam zatrudniona bibliotekarka, towarzyszka Maria Rożenek. Zgodnie z raportem z 1 IX 1949 r. biblioteka mieściła się przy Referacie Propagandy i Oświaty i otwarta była codziennie w godzinach od 9.00 do 13.00. Prowadzono zarówno księgę inwentarzową, jak i katalogi klamrowe, sporządzone zgodnie z instrukcją Komitetu Centralnego i Urzędowym Dziennikiem Rozporządzeń. Biblioteka działała dosyć efektywnie, jednak do grudnia 1950 r. wciąż trwały różnego rodzaju prace remontowe i usprawniające jej działanie $^{30}$. Po 15 IX 1949 r. za pomocą specjalnych nalepek i książek „rozdzielaczy” dokonano podziału zbioru bibliotecznego na działy tematyczne, zamontowano skrzynki katalogowe i wprowadzono metryczki wypożyczeńn ${ }^{31}$. Katalog numeryczny zastąpiono w listopadzie $1949 \mathrm{r}$. katalogiem alfabetycznym z podziałem na działy ${ }^{32}$. Przez pewien czas bibliotekarka prosiła także o przydzielenie lokalu, w którym można byłoby otworzyć czytelnię. Pomieszczenie otrzymano we wrześniu 1950 r., ale wymagało ono kapitalnego remontu, dlatego też czytelnię otworzono dopiero w grudniu tego roku ${ }^{33}$.

Księgozbiór biblioteki zwiększał się stopniowo. Pierwszy zachowany inwentarz pochodzi z listopada 1949 r. i liczy 403 pozycje, co jest wynikiem błędu przy sporządzaniu numeracji, bo w rzeczywistości na liście jest 397 książek. Nie są to rzecz jasna wszystkie pozycje, jedynie te, które udało się do tego czasu zinwentaryzować. Na początku warto zwrócić uwagę na sam opis książek, po

${ }^{29}$ KP PZPR w Lubartowie, sygn. 553, Do Wydziału Propagandy KP PZPR w Lubartowie, k. 6.

${ }^{30} \mathrm{KP}$ PZPR w Lubartowie, sygn. 564, Sprawozdania z pracy biblioteki przy KP PZPR w Lubartowie, k. 1.

${ }^{31}$ Ibidem, k. 2.

32 Ibidem, k. 4.

${ }^{33}$ Ibidem, sygn. 625, Sprawozdania z pracy biblioteki przy KP PZPR w Lubartowie, k. 6, 9. 
nazwisku występuje inicjał imienia, a następnie tytuł. W przypadku kilku dzieł tego samego autora jego dane wpisywane są tylko raz. Należy zwrócić uwagę, że osoba tworząca inwentarz nie ustrzegła się błędów w nazwiskach i tytułach, np. „Żelechowski” zapisano jako „Zelechowski”, a Noce i dnie Marii Dąbrowskiej zapisane są jako Dnie i noc. Nie jest to więc źródło dokładne i pozwalające na wyczerpującą analizę, ale zawiera w sobie wiele cennych z punktu widzenia tego studium informacji.

$\mathrm{Z}$ racji tego, że wielu tytułów $\mathrm{z}$ inwentarza brak we współczesnych katalogach bibliotecznych, nie sposób jednoznacznie określić ich przynależności do konkretnych gatunków literackich. Wydaje się jednak, że dominują książki z obszaru propagandy i edukacji. W inwentarzu widnieje sześć dzieł Stalina, sześć Marksa i 18 autorstwa Lenina. W księgozbiorze znalazły się także biografie socjalistycznych przywódców. Ponadto mnóstwo tytułów o wydźwięku propagandowym, jak Wyższość socjalistycznego systemu gospodarczego nad systemem kapitalistycznym Konstantina Ostrowitjanowa, Tradycja przyjaźni demokratycznej Polski i Rosji Bolesława Drukiera czy Socjalistyczne współzawodnictwo Kuźniecowa oraz liczne broszury o historii i działalności PZPR. Nie zabrakło też książek, które miały wyjaśniać panujący ustrój (np. Socjalizm i komunizm Pawła F. Judyna i Rola jednostki i mas ludowych Teodora V. Konstantinowa). Sporo jest również publikacji o charakterze poradnikowym, jak „Kalendarz Rolniczy”, "Kalendarz Robotniczy”, Renta gruntowa Ostrowitjanowa i Jak sporzadzić testament Włodzimierza Dolińskiego. Co ciekawe, w zbiorach znalazły się także Skrócone przepisy katalogowania Józefa Grycza.

Jeżeli chodzi o naukę i edukację, to dominują książki historyczne, m.in. Polacy rewolucji listopadowej Henryka Raorta, Historia Polski i $Z$ dziejów kapitali$z m u$ w Polsce Grosfelda. Jest też kilka pozycji z nauk ścisłych, jak np.: Pogadanki o dialektyce i matematyce Lidera, Rozwój świata organicznego Włodzimierza Michajłowa, czy Układ planetarny Słońca Jana Gadomskiego. Mimo że księgozbiór biblioteki miał służyć przede wszystkim edukacji i propagandzie, w inwentarzu nie brakuje literatury pięknej. Wiersze Adama Mickiewicza i Leopolda Staffa, powieści Honoriusza Balzaca, Elizy Orzeszkowej, Uptona Sinclaira, Wiktora Hugo i Stefana Żeromskiego z pewnością w jakimś stopniu odpowiadały kulturowym trendom socjalizmu, nie zmienia to jednak faktu, że biblioteki komitetów powiatowych starały się także ukulturalniać członków partii.

W statystykach wypożyczeń z lubartowskiej biblioteki wyraźnie widoczna jest tendencja spadkowa. W sprawozdaniu z października 1949 r. mowa jest o zapisanych 35 czytelnikach, którzy we wrześniu wypożyczyli 50 książek. Po- 
jawia się także prośba o przesłanie Poematu pedagogicznego Antoniego Makarenki, który miał być podstawą do dyskusji na spotkaniu czytelniczym ${ }^{34}$. Wskazuje to na funkcjonowanie koła czytelniczego, jednak w dalszych zachowanych raportach nie ma o nim więcej informacji. Znalazła się natomiast odpowiedź z Wydziału Propagandy KW na prośbę o przysłanie konkretnego tytułu. Poinformowano w niej, że nakład Poematu pedagogicznego został wyczerpany, ale skrót książki ma się pojawić w „Bibliotece Żołnierskiej”. Zachęcano jednocześnie do podawania kolejnych tytułów i autorów, które przydałyby się w bibliotece ${ }^{35}$. Pod koniec grudnia 1949 r. zapisanych było do niej 47 czytelników ${ }^{36}$. Od marca 1950 r. można jednak zaobserwować pewną niewielką, w porównaniu z ogółem zapisanych użytkowników, grupę osób, która z biblioteki korzysta. W tym miesiącu zaledwie 16 osób wypożyczyło 30 książek, gdy cała lista obejmowała już 67 czytelników. W maju 1950 r. było zapisanych 75 użytkowników, ale tylko 19 osób dokonało 29 wypożyczeń. Grudzień 1950 r. to już 100 osób zapisanych do biblioteki, ale zaledwie 48 wypożyczonych książek dla 21 czytelników $^{37}$. Widać zatem, że choć sporo osób posiadało kartę czytelnika, to w praktyce nie korzystała z niej nawet połowa zapisanych. Jedną z przyczyn takiego zjawiska mogło być to, że biblioteka czynna była w godzinach porannych. Co prawda w marcu 1950 r. postulowano zmianę godzin otwarcia na bardziej przystępną dla użytkowników porę popołudniową, jednak prośby tej nie uwzględniono ${ }^{38}$.

\section{Biblioteka KP PZPR w Radzyniu Podlaskim}

Biblioteka ta istniała od $1946 \mathrm{r}^{39}$, a zachowane sprawozdania z jej działalności pochodzą z okresu od stycznia do grudnia 1949 r. Nie miała własnego pomieszczenia, mieściła się w świetlicy komitetu, co bardzo utrudniało jej normalne funkcjonowanie. Początkowo wszelkie prace w bibliotece prowadziły dwie towarzyszki, pierwotnie pracujące jako maszynistki w KP. Planowano zatrudnić też

\footnotetext{
${ }^{34}$ KP PZPR w Lubartowie, sygn. 564, Sprawozdania z pracy biblioteki przy KP PZPR w Lubartowie, k. 3.

${ }^{35}$ Ibidem, sygn. 553, Kierownik Sieci Bibliotecznej do KP PZPR, k. 43.

${ }^{36}$ Ibidem, sygn. 564, Sprawozdania z pracy biblioteki przy KP PZPR w Lubartowie, k. 13.

${ }^{37}$ Ibidem, sygn. 625, Sprawozdanie z pracy biblioteki przy KP PZPR w Lubartowie, k. 1, 3, 9.

${ }^{38}$ Ibidem, k. 3.

${ }^{39}$ KP PZPR w Radzyniu Podlaskim, sygn. 563, Sprawozdanie bibliotekarza przy KP PZPR w Radzyniu Podlaskim, k. 1.
} 
uczennicę gimnazjum, jednak ta, ze względu na obowiązki szkolne, odmówiła prowadzenia biblioteki ${ }^{40}$. Bibliotekarz pojawił się w listopadzie (Sabina Krys), ale był zatrudniony dorywczo. Należy również zauważyć, że oficjalne otwarcie biblioteki nastąpiło dopiero 10 grudnia 1949 r., bo do tego czasu trwały wszystkie prace remontowe i organizacyjne. Co prawda od początku były opracowane katalogi działowy i alfabetyczny oraz inwentarz, ale brakowało podstawowych rzeczy, takich jak skrzynki i karty katalogowe, pieczątki oraz regały, na których można było poustawiać księgozbiór. Zwracano uwagę, że biblioteka posiada tylko jedną dużą szafę na książki, z której korzystanie jest dosyć utrudnione wypożyczenie jednego egzemplarza wiązało się z wyciągnięciem z szafy wielu innych książek, które potem trzeba było ponownie poukładać. Szafa była zamykana, przez co czytelnicy nie mieli wglądu do księgozbioru. Zarówno skrzynki, jak i regały przywieziono tuż przed otwarciem. Początkowo książki udostępniano codziennie, o ile osoba za nie odpowiedzialna była w świetlicy, natomiast od grudnia 1949 r. biblioteka była czynna we wtorki i w piątki od 16.00 do $18.00^{41}$.

W ciekawy sposób prowadzono ewidencję księgozbioru. W inwentarzu znajdowały się tylko książki, natomiast zeszyty i broszury zapisywano w oddzielnych brulionach ${ }^{42}$. Oddzielne prowadzenie ewidencji dla różnego typu materiałów bibliotecznych było rzadkie i wynikało zapewne $\mathrm{z}$ faktu, że prace inwentaryzacyjne prowadziły osoby bez odpowiedniego przygotowania.

Zakupy książek odbywały się w miarę regularnie. Najwięcej książek, bo 98, zakupiono w styczniu 1949 r. ${ }^{43}$ Inwentarz biblioteki Komitetu Powiatowego w Radzyniu Podlaskim został spisany pod koniec 1949 r. Liczył sobie 503 pozycje i był sporządzony w identyczny sposób, jak inwentarz lubartowski. Z tych samych co wcześniej powodów nie da się dokonać pogłębionej analizy księgozbioru, a jedynie przedstawić ogólniejszy stan całości.

Przede wszystkim, pod względem zawartości, księgozbiory są do siebie bardzo zbliżone. Podobnie jak w przypadku Lubartowa, tak i tutaj nie brakuje dzieł Stalina, Lenina, Marksa i Engelsa oraz ich biografii. Do tego dochodzi literatura, mająca na celu wyjaśniać wątpliwości związane z panującym ustrojem, jak Pogadanki z zakresu ekonomii politycznej socjalizmu Włodzimierza Brusa, O radzieckim systemie finansowym Diaczenki, czy Prawo socjalistyczne i jego źródła

\footnotetext{
40 Ibidem, k. 14.

41 Ibidem, k. 17-20.

42 Ibidem, k. 16.

43 Ibidem, k. 12.
} 
Stepana F. Keczekiana. Podobnie jak we wcześniej omawianym księgozbiorze często występują broszury o historii i działalności PZPR i książki o charakterze propagandowym. W przypadku poradników, wiele tytułów się powtarza, do tego biblioteka radzyńska miała aż 29 egzemplarzy zbiorowego „Poradnika Społecznego". Jeśli chodzi o pozycje o charakterze naukowym, to tym razem dominują nauki ścisłe (np. Pochodzenie gór i lądów Władimira Oburczewa, Opowiadania o ziemi Feofana D), później historyczne, takie jak $Z$ dziejów polskiego ruchu robotniczego Franciszka Jóźwiaka i Historyczne znaczenie Konstytucji 3 maja Franciszka Fiedlera. Powtarzają się także nazwiska twórców literatury pięknej.

Jak wcześniej zauważono, mimo że biblioteka oficjalnie zaczęła działać pod koniec grudnia 1949 r., to książki wypożyczano już wcześniej. Jednak dopiero w sprawozdaniu z sierpnia pojawiła się informacja o 12 stałych czytelnikach, informowano również o tym, że część wypożyczeń rejestrowanych jest na komitety gminne i podstawowe organizacje partyjne ${ }^{44}$. Należy zwrócić uwagę, że w raportach wielokrotnie podkreślano słabą frekwencję czytelników, która wynikała zarówno z prowadzonych prac remontowych, jak i samej lokalizacji biblioteki. Szczególnie uskarżano się na trwające ciągle w świetlicy zebrania, które utrudniały pracę bibliotekarzowi i zniechęcały użytkowników do korzystania z księgozbioru. W sprawozdaniu za grudzień 1949 r. jest mowa zaledwie o 22 korzystających, w tym kilku osobach ze szkół średnich. To pokazuje, jak trudności organizacyjne silnie rzutowały na czytelniczą frekwencję ${ }^{45}$.

\section{Biblioteka KP PZPR w Łukowie}

O działalności biblioteki przy Komitecie Powiatowym w Łukowie świadczą trzy sprawozdania. Pierwsze pochodzi z 19 I 1949 r. Zgodnie z podanymi danymi biblioteka istniała od 15 XI 1948 r. i gromadziła 136 książek, z czego 59 zakupiono w styczniu 1949 r. Nie zatrudniono bibliotekarza, brakowało również księgi inwentarzowej, natomiast katalog początkowo prowadzono w postaci brulionów. Mimo to do biblioteki zapisanych było 200 czytelników. Biblioteka była czynna w soboty i wtorki od godziny 16.00 .

Sprawozdania były wysyłane regularnie, o czym świadczyć może zawiadomienie z marca 1949 r. o wysłaniu do KW PZPR formularzy nr 1 i 2, czyli for-

\footnotetext{
44 Ibidem, k. 16.

45 Ibidem, k. 18-20.
} 
mularzy właściwych dla bibliotek. Niemniej kolejne zachowane sprawozdania pochodzą dopiero z $1950 \mathrm{r}$. W dokumencie za marzec widać już spory postęp, poczyniony $w$ organizacji pracy biblioteki. Sporządzono księgę inwentarzową, w której ostatni numer to 750. Ukończone zostały prace nad katalogiem działowym i alfabetycznym. Wciąż nie było zatrudnionego bibliotekarza, ale biblioteką opiekowała się Stanisława Siebielcowa, która przebywała tam w poniedziałki, środy i piątki od 17.00 do 19.00 . Jej praca miała charakter partyjno-społeczny i była bezpłatna. W marcu 1950 r. aż 100 czytelników wypożyczyło 473 książki. Dalsza część dokumentu zawiera informacje o trudnościach, wynikających z pracy biblioteki. Towarzyszka Siebielcowa przez cały kwiecień przebywała na urlopie, co spowodowało spore zaległości w sprawozdawczości i pracy technicznej w bibliotece. Po raz kolejny kobieta apelowała o zatrudnienie bibliotekarza, gdyż sześć godzin w tygodniu, jakie była w stanie przeznaczyć na pracę w bibliotece, nie wystarczało na wykonanie wszystkich prac. Podkreślała też, że w komitecie jest za mało miejsca i należałoby przenieść bibliotekę w inne miejsce.

Ostatnie sprawozdanie pochodzi z czerwca 1950 r. Nie zakupiono wówczas żadnych książek, ale biblioteka posiadała już 828 woluminów. Niestety, wciąż nie zatrudniono bibliotekarza, choć towarzyszka Siebielcowa ponownie o to apelowała. Mimo wielu niedogodności z biblioteki korzystano coraz częściej w czerwcu 1950 r. 108 czytelników wypożyczyło 671 książek, zapisało się dodatkowo 7 użytkowników. W tym samym miesiącu biblioteka została przeniesiona do nowego lokalu, co wiązało się z koniecznością ponownego uporządkowania księgozbioru. Dlatego towarzyszka Siebielcowa prosiła o wizytę dyrektorki biblioteki KW towarzyszki Gruchalskiej, która podałaby jej konkretne wytyczne. W końcowej części sprawozdania Siebielcowa napisała, że „lokal jest piękny, należy tylko dać wytyczne i biblioteka spełni swoje tak zaszczytne cele”, co może wskazywać na to, że mimo uskarżania się na braki kadrowe Siebielcowa była z pracy biblioteki bardzo zadowolona. Widać, że mimo braku wiedzy i doświadczenia Siebielcowa starała się w jak najlepszy sposób prowadzić bibliotekę. Choć nie otrzymywała za to żadnych gratyfikacji, poświęcała placówce swój czas. Zapewne jej wysiłki były jednym z głównych czynników wpływających na wysoki poziom czytelnictwa. 


\section{Biblioteka KP PZPR w Chełmie}

O funkcjonowaniu biblioteki komiteckiej w Chełmie świadczy zaledwie kilka dokumentów, dlatego też zostaną one omówione oddzielnie. Pierwszy, opisujący stan biblioteki na dzień 1 I 1950 r., dostarcza kilku podstawowych informacji. Biblioteka istniała od 15 XII 1949 r. i posiadała 512 książek. Nie było w tym czasie zatrudnionego bibliotekarza, sprawozdania sporządzał Marian Kostka, instruktor propagandy. Księgozbiór pozostawał nieuporządkowany, brakowało podstawowych rzeczy, jak choćby regałów, stąd też nie było wypożyczalni i nikt jeszcze z biblioteki nie korzystał. Funkcjonowała co prawda czytelnia pism przy ośrodku szkolenia partyjnego, ale nie ma informacji o tym, jak i czy w ogóle udostępniano tam książki. W bibliotece brakowało również materiałów dydaktycznych, przydatnych przy prowadzeniu takiej placówki. Zgłaszano też potrzebę otrzymania materiałów do prowadzenia kursów języka rosyjskiego w postaci broszur i stereogramów.

Kolejne odnalezione sprawozdanie pochodzi z 6 II 1950 r. za miesiąc styczeń. W tym czasie biblioteka zakupiła trzy egzemplarze książek, natomiast od wydawnictwa „Książka i Wiedza” otrzymała w darze 22 książki i 28 broszur. Nadal nie zatrudniono bibliotekarza, nie prowadzono też księgi inwentarzowej. Prace porządkowe w lutym ograniczyły się więc jedynie do sporządzenia katalogu działowego.

Ostanie sprawozdanie pochodzi z 8 V 1950 r. i sporządzono je za miesiąc kwiecień. Biblioteka posiadała wówczas 669 książek (52 z nich zakupiono w kwietniu), z czego osiem zostało usuniętych w trakcie akcji oczyszczania księgozbiorów bibliotecznych. Wypożyczono wówczas 31 egzemplarzy 21 czytelnikom, 50 książek zostało oprawionych, a 600 obłożonych papierem. Były już wtedy regały, na których umieszczono rozdzielacze działowe, wyremontowano też lokal biblioteki. Prace organizacyjne w bibliotece oceniono na 75 proc., proszono też o wysłanie 500 kart książek, 500 kart katalogu alfabetycznego i 200 kart czytelnika.

W przypadku księgozbioru biblioteki Komitetu Powiatowego w Chełmie udało się znaleźć tylko rachunek z sierpnia 1949 r. W informacji dołączonej do rachunku jest napisane, że wymienione na rachunku książki trzeba jak najszybciej wpisać do księgi inwentarzowej, a w przypadku kontroli, za brak jakiejkolwiek pozycji będzie odpowiadał bibliotekarz.

Rachunek liczy 60 pozycji, które opisane są w następujący sposób: numer porządkowy, liczba egzemplarzy, nazwisko autora, skrócony tytuł i cena. 
Ów skrótowo zapisany tytuł $\mathrm{w}$ wielu przypadkach uniemożliwia identyfikację dzieła. Koszt wszystkich książek razem z przesyłką wyniósł 15000 złotych. Co ciekawe, na rachunku nie ma tak wszechobecnych dzieł Lenina i Stalina, być może biblioteka miała je już wcześniej. Są za to wymienieni Trzej muszkieterowie i Dwadzieścia lat później Aleksandra Dumasa, Cham Elizy Orzeszkowej, Rok dziewięćdziesiąty trzeci Victora Hugo i kilka dzieł Uptona Sinclaira, amerykańskiego pisarza znanego z socjalistycznych sympatii. Na liście znalazło się też kilka tytułów o charakterze ideologicznym i propagandowym (m.in. O planie trzyletnim Bronisława Minca, Cztery pogadanki o polityce zagranicznej Polski Ludowej), a także radziecka encyklopedia. Ogółem wyraźna jest w tym wypadku przewaga literatury pięknej nad książkami, które miały służyć celom propagandowym i ideologicznym.

\section{Biblioteka KP PZPR w Puławach}

O bibliotece w Puławach wiadomo jeszcze mniej. Z 5 X 1949 r. pochodzi informacja o zatrudnionej tam bibliotekarce, Helenie Pruszyńskiej. Urodzona 15 VI 1884 r. kobieta miała wykształcenie nauczycielskie ze zdaną maturą ${ }^{46}$. Natomiast pierwsze sprawozdanie pochodzi z wcześniejszego okresu, tj. z lutego 1949 r. Zawarta jest w nim informacja, że bibliotekę przejęto po KP PPR z 571 książkami, których liczba szybko wzrosła do 675 egzemplarzy. Z powodu braku bibliotekarza prowadzili ją dorywczo pracownicy komitetu, z tego powodu nie było stałych dni i godzin wypożyczania. Mimo to zapisanych do biblioteki było 34 czytelników. Istniał katalog działowy i księga inwentarzowa, ale z braku odpowiednio przygotowanej do jej opracowania osoby nie była ona ukończona ${ }^{47}$.

Bardziej szczegółowe sprawozdanie datowane jest na 4 V 1949 r. Informuje się w nim, że w związku z nowymi wytycznymi KC w bibliotece trwają intensywne prace organizacyjne. Wiązały się one z ułożeniem książek działami i sprowadzeniem skrzynek katalogowych. Zobowiązano się też wyposażyć bibliotekę we wszystkie potrzebne obiekty do $1 \mathrm{XI}$, a 15 dnia tego miesiąca zorganizować oficjalne otwarcie. Z księgozbioru KP korzystało 48 użytkowników, którzy w kwietniu wypożyczyli 61 książek. Biblioteka miała oddzielny lokal,

46 APL, KP PZPR w Puławach, sygn. 437, Do Komitetu Wojewódzkiego PZPR Wydział Propagandy, Oświaty i Kultury w Lublinie, k. 29.

47 APL, KP PZPR w Puławach, sygn. 445, Sprawozdanie opisowe wg formularza nr 1 i 2, k. 29. 
a książki umieszczono $\mathrm{w}$ trzech szafach. Trzeba w tym momencie zaznaczyć, że w komitecie puławskim zgromadzono aż 1200 książek, których spis miał się pojawić w sprawozdaniu za październik tegoż roku ${ }^{48}$.

Kolejna informacja o bibliotece pochodzi z 29 VIII $1951 \mathrm{r}$. Z okazji dnia promocji Wojska Polskiego w Puławach poszczególne jednostki i zakłady pracy wypożyczyły na wystawę swoje książki. Informacje o poszczególnych egzemplarzach były zapisywane w sposób niepełny, ale w pewnym stopniu udało się je zidentyfikować. W przypadku biblioteki było to siedem tomów Dzieł Adama Mickiewicza, Wojna i pokój Lwa Tołstoja w języku rosyjskim, książka Iwana Piotrowicza Pawłowa, rosyjski podręcznik weterynarii i polski podręcznik poświęcony psychologii zwierząt, dwa tomy dzieł Lenina i jeden autorstwa Iwana Miczurina, lub jemu poświęcony, oraz Historia biezwitnaja ${ }^{49}$.

\section{Biblioteka KP PZPR w Kraśniku}

Z działalności biblioteki Komitetu Powiatowego w Kraśniku odnaleziono tylko jedno sprawozdanie. Formularz nr 1 za marzec 1950 r. zawiera zaledwie garść informacji. Biblioteka istniała od 1949 r., a jej księgozbiór liczył 614 książek. Co ciekawe, zatrudniono bibliotekarkę, Krystynę Stachorę, która jednak nie była włączona do szkolenia partyjnego, a co za tym idzie nie miała specjalnego przygotowania. Katalog biblioteczny wciąż był w opracowaniu, niemniej biblioteka była otwarta we wtorki i piątki od 17.00 do 19.00 . W marcu skorzystało z niej 12 osób. Nie było czytelni pism, ale działała wypożyczalnia. W dokumencie znalazła się też informacja o tym, że w bibliotece przeprowadzono czyszczenie księgozbioru ${ }^{50}$.

Natomiast z krótkiego pisma, jakie wystosował Wydział Propagandy KW do KP PZPR w Kraśniku 26 VI 1950 r. wynika jasno, że biblioteka nie jest prowadzona w sposób prawidłowy, a jej księgozbiór nie został jeszcze odpowiednio zakwalifikowany. W związku ze zbliżającym się 10 VII współzawodnictwem bibliotek apelowano, by szybko uporządkować cały księgozbiór, angażując przy tym innych pracowników komitetu ${ }^{51}$. Wydaje się więc, że biblioteka Komitetu

\footnotetext{
${ }^{48}$ APL, KP PZPR w Puławach, sygn. 437, Sprawozdanie do KC PZPR Dział Biblioteczny, k. 30.

49 APL, KP PZPR w Puławach, sygn. 556, Wykaz imienny książek przeznaczonych na dzień promocji Wojska Polskiego w Puławach sprezentowane przez zakłady pracy w Puławach, k. 36.

${ }^{50}$ KP PZPR w Kraśniku, sygn. 616, Formularz nr 1 za marzec 1950, k. 52.

${ }^{51}$ Ibidem, sygn. 641, Pismo KW PZPR w Lublinie z 26 czerwca 1950, k. 128.
} 
Powiatowego w Kraśniku była bardzo zaniedbana, prowadzona w sposób nieregularny i być może z tego również wynika brak zachowanych sprawozdań.

\section{Inne materiały dotyczące funkcjonowania bibliotek KP}

W przeglądanych źródłach znalazły się też inne dokumenty, które wskazywały na istnienie bibliotek przy danych komitetach powiatowych, czy też obrazowały późniejsze ich losy. Do jednej z grup należą sprawozdania z posiedzeń egzekutywy KP. Wśród omawianych na zebraniach problemów kwestię bibliotek podejmowano rzadko, jednak $\mathrm{w}$ protokołach $\mathrm{z}$ tych spotkań znalazło się kilka ciekawych z punktu widzenia niniejszego opracowania informacji. Wiadomo z nich m.in., że w pierwszej połowie 1949 r. w Chełmie zatrudniona była bibliotekarka Orębska, a sama biblioteka była czynna we wtorki od 14.00 do $17.00^{52}$. Natomiast bibliotekę Komitetu Powiatowego w Lublinie w tym samym roku prowadził niejaki Kilian ${ }^{53}$. W 1950 r. w Lubartowie postanowiono nie tworzyć etatu bibliotekarza, gdyż nie było to powszechne i w innych komitetach powiatowych, a bibliotekę oddać pod opiekę jednej z aktywistek partyjnych za skromnym wynagrodzeniem ${ }^{54}$. Później jednak taki etat został utworzony, o czym świadczy dokument z 1952 r., w którym informuje się, że bibliotekarkę Marię Rożenek zastąpi niejaka Gremlasowa ${ }^{55}$. W Tomaszowie Lubelskim natomiast do pracy w bibliotece wyznaczono pod koniec 1949 r. maszynistkę Helenę Leszek ${ }^{56}$. Z kolei w Biłgoraju w 1950 r. zatrudniona była bibliotekarka Krystyna Majewska, która należała do Komisji Dekoracyjnej Obchodów 1 Maja ${ }^{57}$.

W 1951 r. biblioteka KP PZPR w Lublinie została połączona z biblioteką Komitetu Miejskiego. Z tego też powodu zwolniono ze stanowiska bibliotekarki Danutę Bakalarz ${ }^{58}$. Co ciekawe, tę samą osobę zatrudniono ponownie w 1952 r. ${ }^{59}$

${ }^{52}$ KP PZPR w Chełmie, sygn. 77, Protokół z zebrania egzekutywy KP z 4 V 1949, k. 4, 5.

${ }^{53}$ KP PZPR w Lublinie, sygn. 51, Protokół z zebrania egzekutywy KP z 23 XI 1949, k. 90.

${ }^{54}$ KP PZPR w Lubartowie, sygn. 82, Protokół z zebrania egzekutywy KP z 30 IX 1950, k. 106.

${ }^{55}$ Ibidem, sygn. 91, Protokół z zebrania egzekutywy KP z 27 II 1952, k. 144.

${ }^{56}$ KP PZPR w Tomaszowie Lubelskim, sygn. 55, Protokół z zebrania egzekutywy KP z 27 XII 1949, k. 70.

57 APL, KP PZPR w Biłgoraju, sygn. 6o, Protokół z zebrania egzekutywy KP z 3 IV 1950, k. 52.

${ }^{58}$ KP PZPR w Lublinie, sygn. 55, Protokół z zebrania egzekutywy KP z 16 III 1951, k. 148.

${ }^{59}$ Ibidem, Protokół z zebrania egzekutywy KP z 9 II 1952, k. 28. 
Drobna wzmianka pojawiła się również na temat biblioteki Komitetu Powiatowego w Hrubieszowie. Drugi sekretarz Henryk Zarychta w swojej wypowiedzi z czerwca 1949 r. stwierdzil, że biblioteka została zaniedbana, co miało być wynikiem ogólnej dezorientacji i chaosu w komitecie ${ }^{60}$. Te same informacje z podkreśleniem, że przysłana z KC kartoteka (w domyśle może chodzić o katalog) nie została uzupełniona, pojawia się w innym dokumencie z czerwca 1949 r. i tym razem pochodzi od innej osoby ${ }^{61}$. Widać więc, że na posiedzeniach egzekutywy poruszano przede wszystkim problemy kadrowe.

Innego rodzaju materiałem, który dostarcza informacji o bibliotekach komitetów powiatowych są sprawozdania komisji rewizyjnych, prezentowane $\mathrm{w}$ trakcie powiatowych konferencji sprawozdawczo-wyborczych. I tak w Tomaszowie Lubelskim funkcjonowała biblioteka, ale po zwolnieniu maszynistki Heleny Leszek w 1951 r. zupełnie zaprzestała swojej działalności ${ }^{62}$. W protokole z Zamościa ze stycznia 1952 r. zawarta została informacja, że biblioteka działa, ale od trzech miesięcy brakowało w niej bibliotekarza, który sprawnie by nią pokierowa ${ }^{63}$. Problem z pracownikiem miała też Biała Podlaska, gdzie w $1952 \mathrm{r}$. również podkreślano brak zatrudnionego bibliotekarza ${ }^{64}$. Zgodnie ze spisem inwentaryzacyjnym z 9 XII 1952 r. biblioteka ta mieściła się w siedzibie komitetu, a na jej wyposażeniu było pięć półek na książki ${ }^{65}$. Z kolei w bibliotece w Lubartowie była w 1954 r. zatrudniona bibliotekarka, ale stwierdzono, że swoje zadania wykonuje niesolidnie i nie troszczy się o popularyzację księgozbio$\mathrm{ru}^{66}$. Dobre wieści przynosi sprawozdanie z Łukowa za 1952 r., gdzie jest mowa o zatrudnionej bibliotekarce Salomei Egier ${ }^{67}$. Zgodnie z tym sprawozdaniem biblioteka była czynna codziennie od 16.00 do 19.00 . Niestety, w 1953 r. trafiła pod opiekę Marii Wysokińskiej, której praca i dbałość o bibliotekę zostały ocenione

\footnotetext{
${ }^{60}$ APL, KP PZPR w Hrubieszowie, sygn. 64, Protokół z zebrania egzekutywy KP z 18 vi 1949, k. 4.

${ }^{61}$ Ibidem, sygn. 409, Spostrzeżenie o pracy KP PZPR w Hrubieszowie, k. 16.

${ }^{62}$ KP PZPR w Tomaszowie Lubelskim, sygn. 3, Sprawozdanie komisji rewizyjnej na dzień 8 XII 1951, k. 68.

${ }^{63}$ KP PZPR w Zamościu, sygn. 3, Protokół III Powiatowej Konferencji Sprawozdawczo-Wyborczej z 12-13 I 1952, k. 5.

${ }^{64}$ APL, KP PZPR w Białej Podlaskiej, sygn. 4, Protokół z komisji rewizyjnej przy KP, 1952 r., k. 68 .

${ }^{65}$ Ibidem, Spis inwentaryzacji w KP w dn. 9 XII 1952, k. 78.

${ }^{66}$ KP PZPR w Lubartowie, sygn. 4, Sprawozdanie komisji rewizyjnej KP na V Powiatową Konferencję Sprawozdawczo-Wyborczą [1/19 vi 1954], k. 75.

${ }^{67}$ APL, KP PZPR w Łukowie, sygn. 4, Sprawozdanie powiatowej komisji rewizyjnej za okres między III a IV Powiat. Konferencją Sprawozdawczo-Wyborczą, k. 73.
} 
jako niezadowalające ${ }^{68}$. W 1955 r. pojawia się informacja, że bibliotekę prowadzi Maria Mikiciuk ${ }^{69}$. Nie wiadomo, czy była to ta sama osoba, która w trakcie pracy wyszła za mąż, czy już ktoś inny.

W sprawozdaniach komisji rewizyjnych, podobnie jak w przypadku protokołów posiedzeń egzekutywy, dominują kwestie kadrowe. Nie są to obszerne materiały, ale dają pewien ogląd na kwestię miejsca etatu bibliotekarza w komitecie powiatowym. Widać, że o wiele chętniej oddawano biblioteki pod opiekę niewykwalifikowanych osób, niż zatrudniano doświadczonego pracownika. Źródła te potwierdzają wcześniej przytoczone wytyczne o społeczno-partyjnym i nierzadko wolontariackim charakterze pracy w bibliotekach KP.

\section{Wnioski}

Na podstawie zebranych materiałów można wysnuć pewne ogólne wnioski, dotyczące rzeczywistej roli bibliotek komitetów powiatowych w strukturach oświatowych partii, a także charakteru samego systemu kształcenia wewnątrzpartyjnego. $\mathrm{O}$ ile w założeniu biblioteki miały stanowić bogate zaplecze niezbędnych do samokształcenia materiałów oraz posiadać wykwalifikowany i chętny do pomocy personel, o tyle w praktyce były po prostu zaniedbane. Co ciekawe, ich stan nie wynikał jedynie z braku zaangażowania odpowiedzialnych za nie osób, ale również (a może przede wszystkim) nieodpowiedniej polityki organów nadrzędnych. Postulaty o zwiększenie środków czy wysłanie niezbędnych do poprawnego działania biblioteki materiałów często pozostawały bez odpowiedzi, a zrezygnowani bibliotekarze, mimo najszczerszych chęci, nie mogli przez to sprawnie pracować.

Jak już wcześniej zauważono, biblioteki komitetów powiatowych podlegały kontroli ze strony organów nadrzędnych, jednak wysyłane wciąż pisma ponaglające nie przynosiły wyraźnych skutków. Nie odnaleziono natomiast informacji na temat tego, czy wyciągano w przypadku rażących zaniedbań jakiekolwiek konsekwencje. Rzecz jasna, materiał źródłowy jest bardzo rozproszony, dlatego nie można jednoznacznie stwierdzić, że żadne sankcje nie miały miejsca. Biorąc

${ }^{68}$ Ibidem, Sprawozdanie powiatowej komisji rewizyjnej za okres między IV a v Powiat. Konferencją Sprawozdawczo-Wyborczą, k. 78.

${ }^{69}$ Ibidem, Sprawozdanie powiatowej komisji rewizyjnej za okres między v a vi Powiat. Konferencją Sprawozdawczo-Wyborczą, k. 72. 
jednak pod uwagę fakt, że po stronie Komitetu Wojewódzkiego również dochodziło do licznych zaniedbań, można wysunąć hipotezę, że władze zwierzchnie, świadome swoich własnych niedociągnięć, były w stosunku do komitetów powiatowych pobłażliwe.

Zebrane statystyki dotyczące czytelnictwa jednoznacznie pokazują natomiast, że zaangażowanie pracowników bibliotek było kluczowe dla wzrostu zainteresowania członków partii zgromadzoną przez komitety literaturą. Tam, gdzie aktywność bibliotekarzy była większa, tam książek wypożyczano więcej. Niestety, jak pokazują sprawozdania, z uwagi na warunki pracy bibliotekarzy komitetów oraz trudności związane z pozyskiwaniem podstawowych środków, wielu z pracowników bibliotek szybko traciło zapał i chęć do rozwijania podległej im placówki.

Należy także zwrócić uwagę na to, że księgozbiór bibliotek KP nie ograniczał się jedynie do literatury o charakterze propagandowym i naukowym. Na protokołach $\mathrm{z}$ inwentaryzacji księgozbioru pojawiały się też klasyczne powieści, co może świadczyć o tym, że dbano nie tylko o to, by członkowie partii czytali literaturę fachową, ale również beletrystykę, a co za tym idzie dbali o swój ogólny rozwój.

Analizując powyższe materiały można również odnieść wrażenie, że przynajmniej w pierwszych latach swojej działalności władze PZPR nie potrafiły stworzyć spójnego i realnego programu kształceniowego. Kursy przekładano, a tak cenione samokształcenie było również zaniedbane, choć niebezpośrednio, tylko poprzez liczne niedociągnięcia wobec placówek, które do rozwoju samokształcenia winny się przyczynić - czyli bibliotek komitetów. I to właśnie ich problemy dobitnie pokazują, jak wyglądała propagandowa i oświatowa działalność partii w pierwszych latach jej funkcjonowania. Pierwotne założenia były ambitne i szeroko zakrojone, jednak w zderzeniu z rzeczywistością zawiodła organizacja.

\section{Summary}

\section{Propaganda Activity of District Committees of the Polish United Workers' Party in Lublin Province in the Light of the Activity of Party Libraries in 1948-1952}

The aim of the article is to show the propaganda activity of the Polish United Workers' Party during the first years of its functioning (1948-1952) through the prism of the organization of the district committee libraries. The libraries constituted a very important element of the internal party education system; they 
constituted a support self-education, so important from the party's perspective, Both their holdings and professional staff were expected to encourage people to frequently use the libraries and at the same time to positively influence the intellectual development of the party members. The author, basing on libraries reports, presented the level of the party's preparation for educational and propaganda activities in the field and also the level of its organization.

KEYWORDS: library of the District Committee of the Polish United Workers' Party, PUWP's education, PUWP's propaganda.

\section{Bibliografia}

Chamera-Nowak A., Biblioteki i bibliotekarze partyjni w województwie warszawskim w latach 1949-1954 w świetle dokumentów Komitetu Centralnego PPR oraz Warszawskiego Komitetu Wojewódzkiego PZPR, „Z badań nad książką i księgozbiorami historycznymi”, t. 10, 2016, s. 279-294.

Cichocki B., Jóźwiak K., Najważniejsze są kadry. Centralna Szkoła Partyjna PPR/ PZPR, Warszawa 2006.

Jarosz D., Codzienna mobilizacja. O propagandzie czytelnictwa książek $w$ Polsce stalinowskiej i trudnościach jej badania, „Z badań nad książką i księgozbiorami historycznymi", t. 5, 2011, s. 295-306.

Podstawy wiedzy o PZPR, red. B. Kowalewska i E. Mulicka, Warszawa 1989.

Sowa A. L., Historia polityczna Polski 1944-1991, Kraków 2011.

Zawadka K., Komitet Wojewódzki PZPR w Lublinie 1948-1956. Struktura - ludzie

- mechanizmy funkcjonowania, Lublin 2014. 